\title{
Epigenetic Signatures in Breast Cancer: Clinical Perspective
}

\author{
Paola Parrella \\ Laboratorio di Oncologia, IRCCS Casa Sollievo della Sofferenza, San Giovanni Rotondo (FG), Italy
}

\author{
Key Words \\ Breast cancer - DNA methylation - Early detection
}

\section{Summary}

There is now a compelling body of evidences sustaining the importance of epigenetic mechanisms in the development and progression of cancer. DNA methylation, post-translational histone and other protein modifications, microRNA expression, and nucleosome positioning, all act together to exert their cellular effects. The epigenome is responsible for controlling gene expression thus defining cell differentiation and tissue specificity. This review will focus on DNA methylation and histone modification because these epigenetic events are widely implicated in cancer development and progression. We will in particular address the translational aspects of breast cancer epigenomics including the development of biomarkers and the prospects for epigenetic based pharmacologic treatments. The analysis of DNA methylation has the advantage over other molecular methods (e.g. single gene mutation, microsatellite analysis) that it can be detected with a very high degree of specificity even in the presence of excess unmethylated DNA. Furthermore, the presence of specific $\mathrm{CpG}$ methylation signatures makes methylation-based markers attractive diagnostic, prognostic, and predictive tools for better management of breast cancer patients.

\author{
Schlüsselwörter \\ Mammakarzinom · DNA-Methylierung · Früherkennung
}

\section{Zusammenfassung}

Es gibt inzwischen eindeutige Hinweise darauf, dass epigenetische Mechanismen für die Entwicklung und Progression von Krebserkrankungen von großer Bedeutung sind. DNA-Methylierung, posttranslationale Modifikation von Histonen und anderen Proteinen, microRNA-Expression und Positionierung der Nukleosomen wirken alle zusammen, um so Einfluss auf die Zellen zu nehmen. Das Epigenom ist für die Kontrolle der Genexpression verantwortlich und definiert damit Zelldifferenzierung und Gewebespezifität. Diese Übersichtsarbeit konzentriert sich auf DNA-Methylierung und Histonmodifikation, da diese epigenetischen Ereignisse eng mit der Entwicklung und Progression von Krebserkrankungen verbunden sind. Wir sprechen insbesondere die translationalen Aspekte von Brustkrebs-Epigenomics einschließlich der Entwicklung von Biomarkern und den Aussichten für pharmakologische Behandlungen basierend auf epigenetischen Prinzipien an. Die Analyse der DNA-Methylierung hat im Vergleich zu anderen molekularen Methoden (z.B. Einzelgenmutationen, Mikrosatellitenanalyse) den Vorteil, dass sie mit hoher Spezifität detektiert werden kann, selbst in Gegenwart eines Übermaßes an unmethylierter DNA. Des Weiteren macht die Gegenwart von spezifischen $\mathrm{CpG}$-Methylierungssignaturen methylierungsbasierte Marker zu attraktiven diagnostischen, prognostischen und prädiktiven Werkzeugen für ein verbessertes Management von Brustkrebspatienten.

\begin{tabular}{ll}
\hline KARGER & @ 2010 S. Karger GmbH, Freiburg \\
Fax+497614520714 & Accessible online at: \\
Information@Karger.de & www.karger.com/brc \\
www.karger.com &
\end{tabular}




\section{Introduction}

Epigenetics refer to heritable changes in gene expression that are not associated with modifications in DNA sequences. $\mathrm{CpG}$ island aberrant methylation together with post-transcriptional histone modification play a pivotal role in gene expression regulation and are largely involved in the inactivation of cancer-related genes [1]. In this review, we address the translational aspects of epigenomics in breast tumours with a main focus on the use of epigenetic changes as biomarkers for cancer detection, prognosis, and treatment prediction.

\section{Epigenetics and Gene Expression}

Methylation of promoter $\mathrm{CpG}$ islands is frequently associated with transcriptional silencing of imprinted genes, repeated sequences, and genes on the inactive chromosome X. In healthy cells, the DNA methylation patterns are conserved through cell division allowing the expression of the particular set of cellular genes necessary for that cell type and blocking the expression of exogenous-inserted sequences. Cytosine methylation occurs after DNA synthesis by enzymatic transfer of a methyl group from the methyl donor S-adenosyl-methionine (SAM) to the carbon-5 position of cytosine. Cytosines are methylated in the human genome mostly when located 5' to a guanosine ( $\mathrm{CpG}$ dinucleotide). Interestingly, $\mathrm{CpGs}$ are not equally distributed throughout the genome but are preferentially located in stretches of DNA, ranging from 500 up to 2,000 base pairs in length named $\mathrm{CpG}$ islands, located within and around the promoter region of mammalian genes [2]. CpG DNA methylation is carried out by DNA methyltransferases (DNMTs) with SAM as the methyl donor. Three different DNMTs are involved in establishing and maintaining DNA methylation patterns. A fourth methyl transferase DNMT2 can also be found but its function is still unknown [3, 4]. It is unclear how DNA methylation participates in regulating gene expression. Early studies suggested that some transcription factors might be unable to recognize methylated sequences. However, it now seems that this model can only explain a limited number of cases. An alteration of chromatin structures mediated by repressive histone modifications is another mechanism that may explain the observed transcriptional silencing of methylated genes [5]. Chromatin can exist in an open or closed configuration, the latter is hard to access for the transcriptional machinery. Methylation of the $\mathrm{CpG}$ islands is often associated with chemical modifications in histones suggesting that these proteins are involved in gene expression regulation. The most common studied histone posttranslational modification is the acetylation of a lysine residue of the N-terminal tails. This modification leads to a more open chromatin structure that is more accessible for the transcriptional machinery [6]. Another modification associated with open chromatin status is methylation of histone 3 (H3) at lysine 4 (K4), whereas methylation of $\mathrm{H} 3$ and lysine 9 (K9) or 27 , and of $\mathrm{H} 4$ at lysine $\mathrm{K} 20$, is associated with transcriptional repression [1]. Moreover, a histone variant known as H2a.Z was associated with active chromatin structure and was absent in epigenetically inactivated genes [7]. Histone acetylation is mediated by a group of proteins called histone acetyltransferase (HAT), and the acetyl groups are removed by histone deacetylase (HDAC). These proteins are involved in the regulation of the expression of several genes that play pivotal roles in maintaining cellular homeostasis [8].

\section{Epigenetics and Cancer}

It has been increasingly recognized over the past several years that $\mathrm{CpG}$ islands of a large number of genes, which are mostly unmethylated in normal tissue, are methylated to varying degrees in human cancers, thus representing tumour-specific alterations. In cancer cells, there is a deregulation of DNA methylation patterns that lead to genome-wide hypomethylation and hypermethylation of $\mathrm{CpG}$ islands associated with cancer-related genes. In addition, a large group of cancers are also associated with aberrant HDAC expression [2]. A recent interesting hypothesis suggests that epigenetic modifications may precede the accumulation of genetic events during carcinogenesis. Evidence suggests that adult stem (or stem-like) cells are the target of multiple mutation and epigenetic deregulation that will affect the balance between self-renewal and differentiation leading ultimately to tumour development and progression [9]. Widschwendter et al. [10] have reported that genes targeted by the stem cell Polycomb Repressor Complex 2 (PRC2) are particularly predisposed to cancer-specific DNA hypermethylation. Polycomb group genes define a dynamic cellular identity through the tight regulation of specific gene expression patterns. Thus, epigenetic silencing of specific genes associated with differentiation and development would predispose the stem (or stem-like) cell to carcinogenesis through the acquisition of further genetic events, such as mutations and deletions and additional epigenetic deregulation (fig. 1).

\section{Epigenetics and Cancer Treatment}

An important characteristic of epigenetic events is that they are potentially reversible. Since complete gene silencing requires DNA methylation and histone modifications, both demethylating agents and HDAC inhibitors are necessary to restore expression. The first epigenetic drugs identified were the DNMT-inhibiting nucleoside analogues 5-azacytidine (azacitidine) and 5-aza-2'-deoxycytidine (decitabine). These compounds bind the DNA methyltransferase enzyme in a covalent complex with the DNA resulting in a loss of DNA methylation with each round of cell division [11]. Several 
Fig. 1. Mammary gland carcinogenesis. Carcinogenesis is the result of genetic and epigenetic 'hits' affecting progenitors (stem) cells, determining an initial growth advantage that, through clonal selection processes, leads to the development of pre-invasive lesions leading ultimately to invasive breast cancer and metastatic disease.



studies have demonstrated that re-expression with demethylating drugs of silenced genes has a strong inhibitory effect on proliferation of cancer cells both in vitro and in vivo. However, the clinical use of azacitidine and decitabine is complicated because they are chemically unstable in water, and highly toxic for blood cells of the myeloid lineage. Zebularine and 5-fluoro-2'deoxycidine are also nucleoside analogues but more stable in the aqueous phase and less toxic compared with azacitidine. Zebularine is very promising because it seems to be more selective on cancer cells than non-malignant cells [12]. The demethylating potential of non-nucleoside analogue DNMT inhibitors was described for several drugs (e.g. procainamide, hydralazine, epigallocatechin-3 gallate), but decitabine still remains the more effective DNMT inhibitor. Many HDAC inhibitors have been described so far, and many others are currently under clinical trials [13]. The majority of them are designed to interfere with the enzyme catalytic domain thus blocking substrate recognition and inhibiting gene expression [14, 15]. Currently, only one HDAC inhibitor called vorinostat has been approved for treatment of cutaneous T-cell lymphomas [16].

\section{DNA Methylation-Based Markers in Breast Cancer}

The analysis of methylation profiles in human cancer indicates that hypermethylation of some of the $\mathrm{CpG}$ islands is shared by multiple tumour types, whereas others are methylated in a tumour type-specific manner [17-21]. Moreover, promoter-aberrant methylation seems to be an early event in tumorigenesis, and an increase in the number of methylated genes during progression has been observed in several tumour types including breast cancer $[22,23]$. In a recent study, we found differences in the patterns of methylation in pre-invasive breast lesions (atypical ductal hyperplesia, $\mathrm{ADH}$ and ductal carcinoma in situ, DCIS) as compared with invasive breast cancers [24]. These data further suggest that DNA methylation may represent an interesting target for the development of new molecular markers for the detection of breast cancer cells in tumours and bodily fluids. The most widely used analytical approach for the determination of methylation status is methylation-specific polymerase chain reaction (PCR) (MSP). This method is based on bisulphite conversion of unmethylated cytosin to thymidine while methylated cytosines are protected from conversion. PCR primers are designed to specifically amplify the modified methylated sequence. Semiquantitative approaches which combine the advantages of MSP (high sensitivity, applicability to any CpGs) and real time PCR (rapidity, small quantity of starting DNA, large dynamic range) were also developed and used for methylation detection in tumours and bodily fluids [25, 26].

\section{Early Detection Markers}

The recent decline in the breast cancer mortality rate is due, in part, to early diagnosis by screening mammography. However, given the well recognized limitations of mammography, further advances for early breast cancer detection are clearly needed for a better management of this highly prevalent neoplasm [27]. Table 1 summarizes the potential DNA methylation-based biomarkers for breast cancer early diagnosis. A number of studies have reported the ability to detect breast cancer cells by DNA methylation analysis in fine needle aspirations (FNAs), nipple aspirates, and ductal lavages. FNA cytology is currently implemented in the diagnostic evaluation process of suspicious breast lesions. However, this procedure has false-negative rates ranging from 5 to $30 \%$. In fact, the ac- 
Table 1. Potential DNA methylation based markers for breast cancer early detection

\begin{tabular}{|c|c|c|c|c|c|c|}
\hline $\begin{array}{l}\text { Tissue or body fluid } \\
\text { analyzed }\end{array}$ & Methylated gene & Samples, $\mathrm{n}$ & $\begin{array}{l}\text { Analytical } \\
\text { method }\end{array}$ & Sensitivity, \% & Specificity, \% & Ref. \\
\hline $\begin{array}{c}\text { Benign breast lesions, } \\
\text { DCIS, IDC, FNA }\end{array}$ & $\begin{array}{l}\text { RARß2, RASSF1A, } \\
\text { CCND2 }\end{array}$ & $\begin{array}{l}36 \text { tissues, } 21 \text { DCIS, } \\
45 \text { IDC, } 17 \text { FNA }\end{array}$ & MSP & 67 & 100 & [29] \\
\hline FNA & $\begin{array}{l}\text { CCND2, RASSF1A, } \\
\text { APC, HIN1 }\end{array}$ & 109 tissue, 123 FNA & MSP & 67 & 78 & [30] \\
\hline Nipple aspirate & $\begin{array}{l}\text { CCND2, RAR } \beta 2, \\
\text { TWIST }\end{array}$ & $\begin{array}{l}20 \text { breast cancer, } \\
45 \text { healthy }\end{array}$ & MSP & 85 & 95 & [31] \\
\hline $\begin{array}{l}\text { Breast tumor and paired } \\
\text { preoperative serum } \\
\text { DNA }\end{array}$ & $\begin{array}{l}\text { RASSF1A, APC, } \\
\text { DAPK }\end{array}$ & 34 & MSP & N/A & 100 & [33] \\
\hline $\begin{array}{l}\text { Breast cancer tissue, } \\
\text { normal tissue, serum }\end{array}$ & RASSF1A, RAR $\beta 2$ & 20 & MSP & 88 & 100 & [34] \\
\hline $\begin{array}{l}\text { Breast cancer tissue, } \\
\text { normal tissue, serum }\end{array}$ & $\begin{array}{l}\text { TMS1, BRCA1, } \\
\text { ER } \alpha, \\
\text { PRB }\end{array}$ & 50 & MSP & N/A & N/A & [35] \\
\hline Serum & $\begin{array}{l}\mathrm{p} 16^{\mathrm{INK} 4 \mathrm{~A}}, \mathrm{p} 14^{\mathrm{ARF}}, \\
\mathrm{CCND} 2, \mathrm{SLIT2}\end{array}$ & 36 & MSP & N/A & N/A & [36] \\
\hline $\begin{array}{l}\text { BM aspirates, paired } \\
\text { serum samples }\end{array}$ & $\begin{array}{l}\text { RAR } \beta 2, \text { MGMT, } \\
\text { RASSF1A, APC }\end{array}$ & 33 & QMSP & N/A & N/A & [37] \\
\hline Plasma DNA & $\begin{array}{l}\text { APC, GSTP1, } \\
\text { RASSF1A, RAR } \beta 2\end{array}$ & 93 tumours, 73 controls & QMSP & 62 & 87 & [38] \\
\hline
\end{tabular}

DCIS = Ductal carcinoma in situ; IDC = infiltrating ductal carcinoma; FNA = fine needle aspiration; $\mathrm{BM}=$ bone marrow;

$\mathrm{MSP}=$ methylation-specific polymerase chain reaction; $\mathrm{QMSP}$ = quantitative methylation-specific polymerase chain reaction;

$\mathrm{N} / \mathrm{A}=$ not applicable.

curacy of the analysis depends on the ability of the operator to collect the sample and on the proficiency of the cytopathologist in performing the morphological examination [28]. Although aberrant promoter methylation was detected with high concordance between FNAs and primary tumours, not always the molecular analysis showed better sensitivity and specificity as compared to cytological examination [29, 30]. Most breast cancers arise from the ductal epithelium, thus atypical and malignant cells can be found in ductal lavages or spontaneously produced ductal fluid (nipple aspirate). Cytomorphological analysis of these specimens is often unsatisfactory because of the small amount of cells recovered. The analysis of promoter methylation of CCND2, RAR $\beta 2$ and Twist in ductal lavages allowed the identification of promoter hypermethylation in 17 of 20 fluids from women with a diagnosis of invasive carcinoma, and in 2 of 7 fluids from patients affected by DCIS, whereas only 5 of 45 ductal lavage fluids from healthy women showed methylation at any of the genes tested. Pathologically confirmed breast cancer was subsequently diagnosed in 2 cases with abnormal cytology and methylated genes in the ductal lavages [31]. Serum and plasma are more readily accessible bodily fluids, and collection of the sample does not require the presence of a specialist as with FNAs, nipple aspirates, and ductal lavages. The presence of abnormally high DNA concentrations of methylated DNA in the serum or plasma of patients was demonstrated in various malignant diseases. Although it remains unclear whether release of tumour DNA into plasma is associated with tumour necrosis, apoptotic cell death, or other selective cellular processes, there is evidence that DNA containing the methylation of a specific gene originates from the primary tumour and is not an artefact in the plasma/serum DNA [32]. Dulaimi et al. [33] determined the methylation status of RASSF1A, APC, DAPK in 34 breast cancers and paired sera. Aberrant methylation of one or more genes was found in 32 of $34(94 \%)$ breast tumour DNA. APC was hypermethylated in 15 of 34 cases $(47 \%)$, RASSF1A in 22 of the 34 tumours $(65 \%)$, and DAPK in 17 of $34(50 \%)$ tumours. Methylation in the sera was detected in $26(76 \%)$ of the corresponding serum DNA including DCIS, lobular carcinoma in situ (LCIS), stage I invasive ductal carcinoma, and lobular carcinoma patients. Methylation of APC, RASSF1A, or DAPK was not observed in serum DNA from normal healthy women and patients with inflammatory breast disease or non-neoplastic breast tissue specimens. A gene unmethylated in the tumour DNA was always found to be unmethylated in the matched serum DNA (100\% specificity). Shukla et al. [34] found RASSF1A methylation in 17 of $20(85 \%)$ breast tumours, and RAR 32 methylation in $2 / 20(10 \%)$ breast tumours. Sera from 15 of 20 (75\%) patients showed concordant methylated RASSF1A, with a sensitivity of $88 \%$. In both cases, a gene unmethylated in the tumour DNA was always found to be unmethylated in 
Table 2. Potential prognostic and predictive methylation based biomarkers for breast cancer

\begin{tabular}{|c|c|c|c|c|}
\hline $\begin{array}{l}\text { Tissue or body fluid } \\
\text { analyzed }\end{array}$ & Methylated gene & Samples, $\mathrm{n}$ & Correlation with outcome & Ref. \\
\hline Breast cancer tissue & Cystatin M (CST6) & 93 & significant association with DFI and OS & [39] \\
\hline Breast cancer tissue & Kallikrein 10 (KLK 10) & 93 & significant association with DFI and OS & [40] \\
\hline Breast cancer tissue & RASSF1A & 93 & significant association with DFI & [41] \\
\hline Breast cancer tissue & SFRP5 & 133 & reduced OS $(\mathrm{HR}=4.55)$ & [42] \\
\hline Breast cancer tissue & ID4 & 170 & $\begin{array}{l}\text { significant association with worst RFS and risk for lymph } \\
\text { node metastasis }\end{array}$ & [43] \\
\hline Serum & $\begin{array}{l}\text { APC, } \\
\text { RASSF1A }\end{array}$ & 122 & significantly worst outcome & [44] \\
\hline Serum & $\begin{array}{l}\text { ESR1, APC, HSD17B4, } \\
\text { HIC1, RASSF1A }\end{array}$ & 86 & $\begin{array}{l}\text { increased risk of death for RASSF1A and/or APC } \\
\text { methylation }(\mathrm{RR}=5.7)\end{array}$ & [45] \\
\hline Serum & BRCA1, p16 & 122 & RR of 6.0 if BRCA1 and/or p16 serum DNA methylated & [46] \\
\hline Breast cancer tissue & $\begin{array}{l}\text { PSAT1 out of a panel } \\
\text { of } 117 \text { candidate genes }\end{array}$ & 200 & predicts tamoxifen therapy response and PFS & [47] \\
\hline Breast cancer tissue & CYP1B1B & 148 & predicts response to tamoxifen therapy & [48] \\
\hline Serum & RASSF1A & 148 & $\begin{array}{l}\text { increased risk of relapse }(\mathrm{RR}=5.1) \text { and death }(\mathrm{RR}=6.9) \\
\text { during treatment }\end{array}$ & [49] \\
\hline $\begin{array}{l}\text { Breast cancer tissue } \\
\quad \text { and serum }\end{array}$ & NEUROD1 & $\begin{array}{l}74 \text { cells; } \\
44 \text { core biopsies, } \\
107 \text { serum }\end{array}$ & $\begin{array}{l}\text { ER-negative breast cancers } 10.8 \text {-fold more likely to } \\
\text { respond to chemotherapy; in serum associated with relapse } \\
\text { after chemotherapy }(\mathrm{RR}=6.2) \text { and death }(\mathrm{RR}=14)\end{array}$ & {$[50]$} \\
\hline Breast cancer tissue & PITX2 & 412 & $\begin{array}{l}\text { higher risk to develop distant metastasis }(\mathrm{HR}=1.71) \\
\text { and worst } \mathrm{OS}\end{array}$ & {$[51]$} \\
\hline Breast cancer tissue & PITX2 & 109 & increased risk of distant metastases. & {$[52]$} \\
\hline Breast cancer tissue & PITX2 & 241 & $\begin{array}{l}\text { significant association with high risk of distant recurrence } \\
(\mathrm{HR}=1.66), \text { poor DFS }(\mathrm{HR}=1.47) \text { and } \mathrm{OS}(\mathrm{HR}=2.07)\end{array}$ & {$[53]$} \\
\hline
\end{tabular}

$\mathrm{DFI}=$ Disease-free interval; OS = overall survival; HR = hazard ratio; RFS = relapse-free survival; RR = response rate;

$\mathrm{PFS}=$ progression-free survival; ER = oestrogen receptor; DFS = disease-free survival.

the matched serum DNA yielding a specificity of $100 \%$. Mirza et al. [35] determined the promoter methylation status of TMS1, BRCA1, ER $\alpha$, and PRB promoter regions in 50 breast cancer and paired sera. Thirty-six of $50(72 \%)$ tumours and 32 of $50(64 \%)$ paired sera showed methylation for at least one of these genes. Methylation of 3 genes was detected in 17 of $50(34 \%)$ tumours and 12 of $50(24 \%)$ sera. Sharma et al. [36] investigated the methylation status of CCND2, p16INK4A, p14ARF, and Slit2 in 36 breast cancer and paired sera. Thirtyone $(86 \%)$ tumours and $30(83 \%)$ paired sera showed methylation of at least one of these 4 genes. Methylation frequencies varied from $27 \%$ for CyclinD2, 44\% for p16INK4A, $47 \%$ for $\mathrm{p} 14 \mathrm{ARF}$ to $58 \%$ for Slit2. There was concordance between DNA methylation in tumour and paired serum DNA for each gene. Taback et al. [37] evaluated whether RAR $\beta 2$, MGMT, RASSF1A, and APC methylation could be identified in bone marrow (BM) aspirates and paired serum samples from 33 early-stage breast cancer patients. Methylation was identified in 7 (21\%) of $33 \mathrm{BM}$ aspirates and 9 (27\%) serum samples. In 3 patients, BM and serum were both positive for hypermethylation. The most frequently detected hypermethylation marker was RASSF1A occurring in 7 (21\%) patients. Concordance was present between gene hypermethylation de- tected in BM or serum samples, and paired primary tumours. In another study using a semiquantitative approach, Hoque et al. [38] determined the frequency of aberrant methylation of the genes APC, GSTP1, RASSF1A, and RAR 32 in plasma from 93 women with breast cancer and 76 controls. Cut-off values for positive methylation status were determined by maximizing the sensitivity and specificity for detection of breast cancer in a training set represented by 46 breast cancer cases and 38 controls. The sensitivities and specificities of the optimal cut-off values were then evaluated in an independent validation data set. Methylation of at least one of the 4 genes of interest was detected in 29 of 47 plasma samples from cancer cases (sensitivity $62 \%$ ) and in 5 of 38 control patient samples (specificity $87 \%$ ).

\section{DNA Methylation-Based Prognostic and Predictive Markers}

The potential prognostic and predictive value of DNA methylation-based markers have been investigated in tumour tissue or sera obtained from breast cancer patients (table 2). Methylation status of cystatin M (CST6), kallikrein 10 (KLK10), and RASSF1A was investigated on a cohort of 93 patients in 3 separate studies [39-41]. Multivariate analysis revealed that positive methylation status of these 3 genes was significantly 
associated with disease-free interval (DFI) and overall survival (OS). Veeck J et al. [42] analyzed promoter methylation status of the SFRP5 gene in a series of 168 primary breast cancers, finding methylation in $73 \%$ of the cases. SFRP5 methylation was also associated with reduced OS. The prognostic role of ID4 methylation status was evaluated in 170 breast cancer cases. Methylation was detected in $69 \%$ of the tumours and was associated with unfavourable recurrence-free interval (RFI) and increased risk for lymph node metastasis $(\mathrm{p}=0.030)$ [43]. By using MethyLight, a high-throughput DNA methylation assay, Muller et al. [44] analyzed 39 genes in a gene evaluation set, consisting of 10 sera from metastasized patients, 26 patients with primary breast cancer, and 10 control patients. Multivariate analysis showed methylated RASSF1A and/or APC serum DNA to be independently associated with poor outcome. In another study, APC and RASSF1A were proved to also be independent prognostic parameters in breast cancer patients [45]. Methylation status of BRCA1, p16, and 14-3-3 sigma was examined in the sera of 122 sporadic breast cancer patients and healthy serum controls. Multivariate analysis showed methylated BRCA1 and/or p16 serum DNA to be independently associated with poor outcome [46].

Predicting resistance to endocrine therapy is crucial to improve the management of breast cancer patients. Martens et al. [47], by using a microarray-based technology, analyzed the DNA methylation status of 117 candidate genes in a cohort of 200 steroid hormone receptor-positive tumours of patients who received the antiestrogen tamoxifen as first-line treatment for recurrent breast cancer. Positive methylation status of the PSAT1 promoter region was associated with favourable clinical outcome, and this result was confirmed by an independent quantitative DNA methylation detection method. The analysis of ESR1 and CYP1B1 promoter regions in 148 breast cancers indicated that ESR1 methylation was a better predictor of clinical response in patients treated with tamoxifen than steroid hormone receptor status, whereas promoter methylation of the CYP1B1 gene was able to predict response differentially in tamoxifen-treated and tamoxifenuntreated patients [48].

Adjuvant systemic therapy is a strategy that targets potential disseminated tumour cells after complete removal of the tumour that has improved survival of cancer patients. To date, no tool is available to monitor efficacy of these therapies, unless distant metastases arise. Fiegl et al. [49] analyzed RASSF1A DNA methylation in pretherapeutic sera and serum samples collected 1 year after surgery from 148 patients with breast cancer, who were receiving adjuvant tamoxifen. RASSF1A methylation status determined 1 year after surgery was an independent predictor of poor outcome suggesting that measurement in serum is able to monitor the efficacy of adjuvant therapy. In another study, promoter methylation of the NEUROD1 gene was able to predict the response to neoadjuvant and adjuvant chemotherapy. NEUROD1 methylation was determined in 74 breast cancer tissue samples, two independent sets of pretreatment core biopsies of 23 (training set) and 21 (test set) neoadjuvantly treated breast cancer patients, and pre-therapeutic and post-therapeutic serum samples from 107 breast cancer patients treated with adjuvant chemotherapy. Oestrogen receptor-negative breast cancers with high NEUROD1 methylation were 10.8fold more likely to respond with a complete pathologic response following neoadjuvant chemotherapy. Patients with persistent positive NEUROD1 methylation after chemotherapy were at higher risk of relapse and showed a worse OS and increased relative risk for death [50]. In a study conducted by the European Organisation for Research and Treatment of Cancer (EORTC) PathoBiology group, the analysis of 117 candidate genes using a methylation microarray in hormone receptor-positive tumours from 109 breast cancer patients treated with adjuvant tamoxifen identified PITX2 as the strongest predictor of distant recurrence [51]. This association with patient outcome was confirmed in two subsequent studies by analyzing 412 lymph node-negative hormone receptor-positive breast cancer patients who had not received any adjuvant systemic treatment, and 241 breast cancer specimens respectively [52, 53].

\section{Histone Modification-Based Markers in Breast Cancer}

A number of studies have investigated the use of histone modifications as biomarkers in tumours [54-57]. In breast cancer, Elsheikh et al. [58] analyzed by immunohistochemistry a series of histone lysine acetylation (H3K9ac, H3K18ac, $\mathrm{H} 4 \mathrm{~K} 12 \mathrm{ac}$, and H4K16ac), lysine methylation (H3K4me2 and $\mathrm{H} 4 \mathrm{~K} 20 \mathrm{me} 3)$, and arginine methylation (H4R3me2) in 880 human breast carcinomas. Correlation with clinicopathological characteristics demonstrated a highly significant correlation between histone modification status, tumour biomarker phenotype, and clinical outcome. High relative levels of global histone acetylation and methylation were associated with a favourable prognosis, and were detected almost exclusively in luminal-like breast tumours (93\%). Moderate to low levels of lysine acetylation (H3K9ac, H3K18ac, and H4K12ac), lysine (H3K4me2 and H4K20me3), and arginine methylation (H4R3me2) were observed in tumours characterized by poorer prognosis (e.g. basal-like tumours and HER-2-positive tumours). Clustering analysis identified 3 groups of histone status patterns which correlates with clinical outcome.

\section{Future Prospectives}

The search for epigenetic-based markers in breast cancer has come a long way in recent years, but no single identified marker has made the transition into the clinic. In the case of early detection markers, the principal limitation of this approach seems to be the underperformance of the majority of 
known markers for a sensitive and specific detection of cancer cells. Thus, an expansion of the currently known methylation markers to other relevant and specific tumour suppressor genes is likely to increase the sensitivity and specificity of the detection. Another aspect that still needs to be addressed is the development of robust panels able to distinguish epigenetic patterns between malignant and non-malignant cells and tumours at different stages. With regard to the prognostic and predictive value of epigenetic changes, larger clinical trials are needed to validate results so far obtained.

\section{Acknowledgements}

This work was supported by the Italian Health Ministry Grants: Integrated Project 'Validazione clinica e analitica di markers biomolecolari di diagnosi oncologica su materiale biologico ottenuto con tecniche non invasive'.

\section{Conflict of Interest}

The author declares that she has no potential conflicts of interests.

\section{References}

1 Esteller M: Epigenetics in cancer. N Engl J Med 2008;358:1148-1159.

2 Jones PA, Baylin SB: The fundamental role of epigenetic events in cancer. Nat Rev Genet 2002;3: 415-428.

3 Okano M, Bell DW, Haber DA, Li E: DNA methyltransferases Dnmt3a and Dnmt3b are essential for de novo methylation and mammalian development. Cell 1999;99:247-257.

$\checkmark 4$ Holliday R: DNA methylation and epigenetic inheritance. Philos Trans R Soc Lond B Biol Sci 1990; 326:329-338.

5 Wade PA: Methyl CpG binding proteins: coupling chromatin architecture to gene regulation. Oncogene 2001;20:3166-3173.

6 Gregory PD, Wagner K, Horz W: Histone acetylation and chromatin remodeling. Exp Cell Res 2001 265:195-202.

7 Witcher M, Emerson BM: Epigenetic silencing of the p16(INK4a) tumor suppressor is associated with loss of CTCF binding and a chromatin boundary. Mol Cell 2009;34:271-284.

8 De Ruijter AJ, van Gennip AH, Caron HN, Kemp $\mathrm{S}$, van Kuilenburg AB: Histone deacetylases (HDACs): characterization of the classical HDAC family. Biochem J 2003;370:737-749.

$\checkmark$ Adams JM, Kelly PN, Dakic A, Carotta S, Nutt SL, Strasser A: Role of 'cancer stem cells' and cell survival in tumor development and maintenance. Cold Spring Harb Symp Quant Biol 2008;73:451-459.

10 Widschwendter M, Fiegl H, Egle D, Mueller-Holzner E, Spizzo G, Marth C, Weisenberger DJ, Campan M, Young J, Jacobs I, et al.: Epigenetic stem cell signature in cancer. Nat Genet 2007;39:157-158.

-11 Egger G, Liang G, Aparicio A, Jones PA: Epigenetics in human disease and prospects for epigenetic therapy. Nature 2004;429:457-463.

12 Cheng JC, Yoo CB, Weisenberger DJ, Chuang J, Wozniak C, Liang G, Marquez VE, Greer S, Orntoft $\mathrm{TF}$, Thykjaer T, et al.: Preferential response of cancer cells to zebularine. Cancer Cell 2004;6:151-158.

13 Kristensen LS, Nielsen HM, Hansen LL: Epigenetics and cancer treatment. Eur J Pharmacol 2009; 625:131-142.

14 Bicaku E, Marchion DC, Schmitt ML, Munster PN: Selective inhibition of histone deacetylase 2 silences progesterone receptor-mediated signaling. Cancer Res 2008;68:1513-1519.

-15 Oehme I, Deubzer HE, Wegener D, Pickert D, Linke JP, Hero B, Kopp-Schneider A, Westermann F, Ulrich SM, von Deimling A, et al.: Histone deacetylase 8 in neuroblastoma tumorigenesis. Clin Cancer Res 2009;15:91-99.

16 Mai A, Altucci L: Epi-drugs to fight cancer: from chemistry to cancer treatment, the road ahead. Int J Biochem Cell Biol 2009;41:199-213.
7 Esteller M, Corn PG, Baylin SB, Herman JG: A gene hypermethylation profile of human cancer. Cancer Res 2001;61:3225-3229.

18 Costello JF, Fruhwald MC, Smiraglia DJ, Rush LJ, Robertson GP, Gao X, Wright FA, Feramisco JD, Peltomaki P, Lang JC, et al.: Aberrant CpG-island methylation has non-random and tumour-typespecific patterns. Nat Genet 2000;24:132-138.

19 Parrella P, Poeta ML, Gallo AP, Prencipe M, Scintu M, Apicella A, Rossiello R, Liguoro G, Seripa D, Gravina C, et al.: Nonrandom distribution of aberrant promoter methylation of cancer-related genes in sporadic breast tumors. Clin Cancer Res 2004;10:5349-5354.

20 Nass SJ, Herman JG, Gabrielson E, Iversen PW, Parl FF, Davidson NE, Graff JR: Aberrant methylation of the estrogen receptor and E-cadherin 5 $\mathrm{CpG}$ islands increases with malignant progression in human breast cancer. Cancer Res 2000;60:43464348.

21 Bae YK, Brown A, Garrett E, Bornman D, Fackler MJ, Sukumar S, Herman JG, Gabrielson E: Hypermethylation in histologically distinct classes of breast cancer. Clin Cancer Res 2004;10:5998-6005.

22 Lehmann U, Langer F, Feist H, Glockner S, Hasemeier B, Kreipe H: Quantitative assessment of promoter hypermethylation during breast cancer development. Am J Pathol 2002;160:605-612.

23 Subramaniam MM, Chan JY, Soong R, Ito K, Ito Y, Yeoh KG, Salto-Tellez M, Putti TC: RUNX3 inactivation by frequent promoter hypermethylation and protein mislocalization constitute an early event in breast cancer progression. Breast Cancer Res Treat 2009;113:113-121.

24 Hoque MO, Prencipe M, Poeta ML, Barbano R, Valori VM, Copetti M, Gallo AP, Brait M, Maiello E, Apicella A, et al.: Changes in $\mathrm{CpG}$ islands promoter methylation patterns during ductal breast carcinoma progression. Cancer Epidemiol Biomarkers Prev 2009;18:2694-2700.

25 Herman JG, Graff JR, Myohanen S, Nelkin BD, Baylin SB: Methylation-specific PCR: a novel PCR assay for methylation status of $\mathrm{CpG}$ islands. Proc Natl Acad Sci U S A 1996;93:9821-9826.

26 Lo YM, Wong IH, Zhang J, Tein MS, Ng MH, Hjelm NM: Quantitative analysis of aberrant p16 methylation using real-time quantitative methylation-specific polymerase chain reaction. Cancer Res 1999;59:3899-3903.

27 Jemal A, Siegel R, Ward E, Hao Y, Xu J, Thun MJ: Cancer statistics, 2009. CA Cancer J Clin 2009;59: 225-249.

28 Barrows GH, Anderson TJ, Lamb JL, Dixon JM: Fine-needle aspiration of breast cancer. Relationship of clinical factors to cytology results in 689 primary malignancies. Cancer 1986;58:1493-1498.
9 Pu RT, Laitala LE, Alli PM, Fackler MJ, Sukumar S, Clark DP: Methylation profiling of benign and malignant breast lesions and its application to cytopathology. Mod Pathol 2003;16:1095-1101.

30 Jeronimo C, Costa I, Martins MC, Monteiro P, Lisboa S, Palmeira C, Henrique R, Teixeira MR, Lopes C: Detection of gene promoter hypermethylation in fine needle washings from breast lesions. Clin Cancer Res 2003;9:3413-3417.

31 Evron E, Dooley WC, Umbricht CB, Rosenthal D, Sacchi N, Gabrielson E, Soito AB, Hung DT, Ljung B, Davidson NE, et al.: Detection of breast cancer cells in ductal lavage fluid by methylationspecific PCR. Lancet 2001;357:1335-1336.

32 Muller HM, Widschwendter M: Methylated DNA as a possible screening marker for neoplastic disease in several body fluids. Expert Rev Mol Diagn 2003;3:443-458.

33 Dulaimi E, Hillinck J, Ibanez de Caceres I, AlSaleem T, Cairns P: Tumor suppressor gene promoter hypermethylation in serum of breast cancer patients. Clin Cancer Res 2004;10:6189-6193.

34 Shukla S, Mirza S, Sharma G, Parshad R, Gupta SD, Ralhan R: Detection of RASSF1A and RARbeta hypermethylation in serum DNA from breast cancer patients. Epigenetics 2006;1:88-93.

35 Mirza S, Sharma G, Prasad CP, Parshad R, Srivastava A, Gupta SD, Ralhan R: Promoter hypermethylation of TMS1, BRCA1, ERalpha and PRB in serum and tumor DNA of invasive ductal breast carcinoma patients. Life Sci 2007;81:280-287.

36 Sharma G, Mirza S, Prasad CP, Srivastava A, Gupta SD, Ralhan R: Promoter hypermethylation of p16INK4A, p14ARF, CyclinD2 and Slit2 in serum and tumor DNA from breast cancer patients. Life Sci 2007;80:1873-1881.

37 Taback B, Giuliano AE, Lai R, Hansen N, Singer FR, Pantel K, Hoon DS: Epigenetic analysis of body fluids and tumor tissues: application of a comprehensive molecular assessment for early-stage breast cancer patients. Ann N Y Acad Sci 2006; 1075:211-221.

38 Hoque MO, Feng Q, Toure P, Dem A, Critchlow CW, Hawes SE, Wood T, Jeronimo C, Rosenbaum E, Stern J, et al.: Detection of aberrant methylation of four genes in plasma DNA for the detection of breast cancer. J Clin Oncol 2006;24:4262-4269.

39 Kioulafa M, Balkouranidou I, Sotiropoulou G, Kaklamanis L, Mavroudis D, Georgoulias V, Lianidou ES: Methylation of cystatin M promoter is associated with unfavorable prognosis in operable breast cancer. Int J Cancer 2009:125:2887-2892.

40 Kioulafa M, Kaklamanis L, Mavroudis D, Georgoulias V, Lianidou ES: Prognostic significance of RASSF1A promoter methylation in operable breast cancer. Clin Biochem 2009;42:970-975. 
41 Kioulafa M, Kaklamanis L, Stathopoulos E, Mavroudis D, Georgoulias V, Lianidou ES: Kallikrein 10 (KLK10) methylation as a novel prognostic biomarker in early breast cancer. Ann Oncol 2009;20: 1020-1025.

42 Veeck J, Geisler C, Noetzel E, Alkaya S, Hartmann A, Knuchel R, Dahl E: Epigenetic inactivation of the secreted frizzled-related protein-5 (SFRP5) gene in human breast cancer is associated with unfavorable prognosis. Carcinogenesis 2008;29:991-998.

43 Noetzel E, Veeck J, Niederacher D, Galm O, Horn F, Hartmann A, Knuchel R, Dahl E: Promoter methylation-associated loss of ID4 expression is a marker of tumour recurrence in human breast cancer. BMC Cancer 2008;8:154.

44 Muller HM, Widschwendter A, Fiegl H, Ivarsson L, Goebel G, Perkmann E, Marth C, Widschwendter M: DNA methylation in serum of breast cancer patients: an independent prognostic marker. Cancer Res 2003;63:7641-7645.

45 Muller HM, Fiegl H, Widschwendter A, Widschwendter M: Prognostic DNA methylation marker in serum of cancer patients. Ann N Y Acad Sci 2004;1022:44-49.

46 Jing F, Jun L, Yong Z, Wang Y, Fei X, Zhang J, $\mathrm{Hu}$ L: Multigene methylation in serum of sporadic Chinese female breast cancer patients as a prognostic biomarker. Oncology 2008;75:60-66.

47 Martens JW, Nimmrich I, Koenig T, Look MP, Harbeck N, Model F, Kluth A, Bolt-de Vries J, Sieuwerts AM, Portengen H, et al.: Association of DNA methylation of phosphoserine aminotransferase with response to endocrine therapy in patients with recurrent breast cancer. Cancer Res 2005;65:4101-4117.
48 Widschwendter M, Siegmund KD, Muller HM, Fiegl H, Marth C, Muller-Holzner E, Jones PA, Laird PW: Association of breast cancer DNA methylation profiles with hormone receptor status and response to tamoxifen. Cancer Res 2004;64: 3807-3813.

49 Fiegl H, Millinger S, Mueller-Holzner E, Marth C, Ensinger C, Berger A, Klocker H, Goebel G, Widschwendter M: Circulating tumor-specific DNA: a marker for monitoring efficacy of adjuvant therapy in cancer patients. Cancer Res 2005;65:1141-1145.

50 Fiegl H, Jones A, Hauser-Kronberger C, Hutarew G, Reitsamer R, Jones RL, Dowsett M, MuellerHolzner E, Windbichler G, Daxenbichler G, et al.: Methylated NEUROD1 promoter is a marker for chemosensitivity in breast cancer. Clin Cancer Res 2008;14:3494-3502.

51 Maier S, Nimmrich I, Koenig T, EppenbergerCastori S, Bohlmann I, Paradiso A, Spyratos F, Thomssen C, Mueller V, Nahrig J, et al.: DNAmethylation of the homeodomain transcription factor PITX2 reliably predicts risk of distant disease recurrence in tamoxifen-treated, node-negative breast cancer patients - technical and clinical validation in a multi-centre setting in collaboration with the European Organisation for Research and Treatment of Cancer (EORTC) PathoBiology group. Eur J Cancer 2007;43:1679-1686.

52 Nimmrich I, Sieuwerts AM, Meijer-van Gelder ME, Schwope I, Bolt-de Vries J, Harbeck N, Koenig T, Hartmann O, Kluth A, Dietrich D, et al.: DNA hypermethylation of PITX2 is a marker of poor prognosis in untreated lymph node-negative hormone receptor-positive breast cancer patients. Breast Cancer Res Treat 2008;111:429-437.
53 Hartmann O, Spyratos F, Harbeck N, Dietrich D, Fassbender A, Schmitt M, Eppenberger-Castori S, Vuaroqueaux V, Lerebours F, Welzel K, et al.: DNA methylation markers predict outcome in node-positive, estrogen receptor-positive breast cancer with adjuvant anthracycline-based chemotherapy. Clin Cancer Res 2009;15:315-323.

54 Ellinger J, Kahl P, von der Gathen J, Rogenhofer S, Heukamp LC, Gutgemann I, Walter B, Hofstadter F, Buttner R, Muller SC, et al.: Global levels of histone modifications predict prostate cancer recurrence. Prostate 2010;70:61-69.

55 Halaban R, Krauthammer M, Pelizzola M, Cheng E, Kovacs D, Sznol M, Ariyan S, Narayan D, Bacchiocchi A, Molinaro A, et al.: Integrative analysis of epigenetic modulation in melanoma cell response to decitabine: clinical implications. PLoS One 2009; 4:e4563.

56 Weichert W, Roske A, Gekeler V, Beckers T, Stephan C, Jung K, Fritzsche FR, Niesporek S, Denkert C, Dietel M, et al.: Histone deacetylases 1,2 and 3 are highly expressed in prostate cancer and HDAC2 expression is associated with shorter PSA relapse time after radical prostatectomy. Br J Cancer 2008;98:604-610.

57 Marquard L, Gjerdrum LM, Christensen IJ, Jensen PB, Sehested M, Ralfkiaer E: Prognostic significance of the therapeutic targets histone deacetylase 1, 2, 6 and acetylated histone $\mathrm{H} 4$ in cutaneous $\mathrm{T}$ cell lymphoma. Histopathology 2008;53:267-277.

58 Elsheikh SE, Green AR, Rakha EA, Powe DG, Ahmed RA, Collins HM, Soria D, Garibaldi JM, Paish CE, Ammar AA, et al: Global histone modifications in breast cancer correlate with tumor phenotypes, prognostic factors, and patient outcome. Cancer Res 2009;69:3802-3809. 